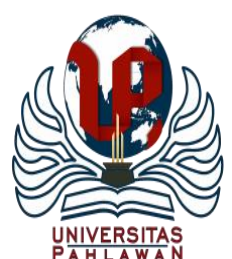

Jurnal Abdidas Volume 2 Nomor 6 Tahun 2021 Halaman 1432 - 1436

JURNAL ABDIDAS

http://abdidas.org/index.php/abdidas

\title{
Penyuluhan Bahaya Pergaulan Bebas dan LGBT pada Remaja Wirid Masjid Nurul Ikhlas Kelurahan Pegambiran Padang
}

\author{
Rahmadhani $^{1 凶}$, Deni Maisa Putra ${ }^{2}$, Yulfa Yulia ${ }^{3}$ \\ Rekam Medis dan Informasi Kesehatan, Stikes Dharma Landbouw Padang, Indonesia ${ }^{1,2,3}$ \\ E-mail: Rahmadhani17387@gmail.com ${ }^{1}$ yulfayuliayy@gmail.com ${ }^{2}$ denimaisaputra@gmail.com ${ }^{3}$
}

\begin{abstract}
Abstrak
Pada zaman era teknologi dimana semakin berkembang semakin beragam pula tingkah laku serta masalah sosial yang terjadi di masyarakat terutama masalah remaja. Perkembangan teknologi yang telah banyak memberi pengaruh buruk bagi remaja sehingga menyebabkan terjadinya kenakalan remaja. Berdasarkan data di Indonesia wilayah Sumatera Barat 2018 di 4 titik yaitu Kota Padang, Bukittinggi, Solok dan Kabupaten Solok diperkirakan 14.469 orang pelaku hubungan lelaki seks dan lelaki (LSL) atau gay di Sumbar. Masa remaja merupakan masa dimana seorang individu mengalami peralihan dari satu tahap ke tahap berikutnya dan mengalami perubahan baik emosi, tubuh, minat, pola perilaku, dan juga penuh dengan masalah-masalah. Remaja yang disebabkan orang tuanya yang terlalu kejam, tidak dapat menyesuaikan didikan dengan keperluan anak untuk berautonomi, ataupun sebaliknya menyebabkan orang tua tersebut tidak peduli untuk memantau perkembangan sosial anak tersebut. Pelajar seperti ini berpotensi untuk mencari teman sebaya yang mempunyai masalah yang kemudian menjadi faktor penarik untuk terlibat dalam gejala sosial. Kekecewaan terhadap keluarga ataupun lingkungan sekitarnya terus berpengaruh kepada perilaku remaja yang menyimpang untuk mengespresikan untuk disayangi menyebabkan individu resah takut ditinggalkan dan sanggup melakukan apa saja untuk mendapatkan kasih sayang.
\end{abstract}

Kata kunci: pergaulan bebas, LGBT

\begin{abstract}
In the era of technology, where it is growing, the behavior and social problems that occur in society are increasingly diverse, especially adolescent problems. The development of technology has had a lot of negative effects on teenagers, causing juvenile delinquency. Based on data in Indonesia in the West Sumatra region in 2018 at 4 points, namely the City of Padang, Bukittinggi, Solok and Solok Regency, it is estimated that 14,469 people who have sex with men (MSM) or gay in West Sumatra. Adolescence is a time when an individual experiences a transition from one stage to the next and experiences changes in both emotions, bodies, interests, behavior patterns, and is also full of problems. Adolescents who are caused by parents who are too cruel, cannot adapt their education to the child's needs for autonomy, or vice versa cause these parents to not care about monitoring the child's social development. Students like this have the potential to find peers who have problems which then become a pull factor to get involved in social phenomena. Disappointment with family or the surrounding environment continues to affect adolescent behavior that deviates from expressing to be loved, causing restless individuals to fear being left behind and being able to do anything to get love.
\end{abstract}

Keywords: free association, LGBT

Copyright (c) 2021 Rahmadhani, Deni Maisa Putra, Yulfa Yulia

$\triangle$ Corresponding author

Address : Stikes Dharma Landbouw Padang

Email : Rahmadhani17387@gmail.com

DOI : https://doi.org/10.31004/abdidas.v2i6.474

ISSN 2721-9224 (Media Cetak)

ISSN 2721- 9216 (Media Online) 


\section{PENDAHULUAN}

Melihat berbagai fakta yang terjadi saat ini, tidak sedikit para pemuda dan pemudi yang terjerumus ke dalam lembah perzinahan (free sex), disebabkan terlalu jauhnya kebebasan mereka dalam bergaul, faktor utama masalahnya adalah kurangnya pemahaman masyarakat saat ini terhadap batas-batas pergaulan antara pria dan wanita. Disamping itu didukung oleh arus modernisasi yang telah mengglobal dan lemahnya benteng keimanan kita mengakibatkan masuknya budaya asing tanpa penyeleksian yang ketat.Pergaulan bebas merupakan pergaulan yang menyimpang, dengan pergaulan remaja yang menyimpang dan yang biasanya mengarah terhadap perbuatan seks. Pada zaman di Era teknologi dimana semakin berkembang semakin beragam pula tingkah laku serta masalah sosial yang terjadi di masyarakat terutama masalah remaja. Perkembangan teknologi sekarang ini telah banyak memberi pengaruh buruk bagi remaja sehingga menyebabkan terjadinya kenakalan remaja. Masa remaja merupakan masa dimana seorang individu mengalami peralihan dari satu tahap ke tahap berikutnya dan mengalami perubahan baik emosi, tubuh, minat, pola perilaku dan juga penuh dengan masalah-masalah (Hurlock dalam Roy, 2011).

Pergaulan bebas anak usia remaja pada era milenial masih menjadi polemik. Era milenial berjalan semakin cepat seiring dengan diikutinya peningkatan kemajuan teknologi yang memberikan nilai tambah dengan mudahnya mengakses segala informasi, hal ini memiliki dampak terhadap pola kehidupan masyarakat dari berbagai kalangan terutama anak usia remaja. Masa remaja merupakan masa peralihan masa kanak remaja menuju masa dewasa. Dimana pada masa ini remaja mulai belajar memiliki tanggung jawab sebagai seorang remaja yang mampu berfikir dan bertindak sesuai dengan norma yang berlaku di masyarakat. Namun adanya arus modernisasi pada era ini memberikan kemudahan bagi remaja untuk mengakses segala informasi dan seluk beluk mengenai hal-hal yang berbau dengan pergaulan bebas.

LGBT (Lesbian, Gay, Biseksual, Transgender) merupakan istilah yang digunakan pada tahun 1990 an untuk menggantikan frasa "komunitas gay". Siapa saja yang melakukan homoseksual atau seks antar jenis hanya dipandang sebagai pelaku temporer dari perbuatan yang dianggap cabul dan menyimpang(Aziz, 2017). Lesbian, Gay, Bisexual dan Transgender (LGBT) merupakan penyimpangan orientasi seksual yang bertentangan dengan fitrah manusia, agama dan adat masyarakat Indonesia.

Jumlah LGBT di Indonesia belum memiliki angka pasti namun jumlahnya diperkirakan meningkat setiap tahun. HIV di Indonesia wilayah Sumatera Barat Tahun 2018 di 4 titik yaitu Kota Padang, Bukittinggi, Solok dan Kabupaten Solok diperkirakan terdapat 14.469 orang pelaku.

\section{METODE}

Sebelum melakukan kegiatan PKM, dilakukan terlebih dahulu observasi dan survei ke wilayah kerja Pegambiran Kecamatan Lubuk Begalung Kota Padang. Setelah dicari Masjid Nurul Ikhlas Pegambiran Kecamatan Lubuk 
1434 Penyuluhan Bahaya Pergaulan Bebas dan LGBT pada Remaja Wirid Masjid Nurul Ikhlas Kelurahan Pegambiran Padang - Rahmadhani, Deni Maisa Putra, Yulfa Yulia

DOI: https://doi.org/10.31004/abdidas.v2i6.474

Begalung Padang dan ditemui pengurus Masjid untuk melakukan penyuluhan kepada siswa-siswi yang wirid remaja yang dilaksanakan pada tanggal 30 Oktober 2021. Dalam kegiatan PKM ini dilaksanakan penyuluhan kepada 30 orang yang berada di sekitar Masjid Nurul Ikhlas Pegambiran Padang. Panitia PKM juga melakukan rapat untuk kegiatan berlangsung persiapan antara lain:

1. Laptop

2. Kabel VGA

3. Kabel Listrik

4. Projector

5. Wireles Pointer

6. Sound System

7. Materi presentasi

8. Konsumsi

9. Dokumentasi

10. Daftar hadir peserta

\section{HASIL DAN PEMBAHASAN}

Sesuai dengan kesepakatan bahwa kegiatan PKM dilaksanakan pada hari Sabtu, tanggal 30 Oktober 2021, dimulai pada jam 20.00 WIB dan berakhir jam 21.30 WIB. Sebelum kegiatan dimulai sudah dilakukan persiapan lokasi dan kelengkapan peralatan dan kebutuhan yang nantinya diperlukan selama acara berlangsung.

Adapun susunan kegiatan secara umum adalah sebagai berikut:

1. Pembukaan oleh moderator

Selain memulai acara, dalam hal ini moderator juga memperkenalkan diri dan menjelaskan secara singkat tentang materi yang akan disampaikan.
2. Kata sambutan oleh pengurus Masjid Nurul Ikhlas Pegambiran Kecamatan Lubuk Begalung Padang

3. Moderator mempersilahkan narasumber untuk menyampaikan materi yang akan disajikan dalam kegiatan PKM di Masjid Nurul Ikhlas Pegambiran Kecamatan Lubuk Begalung Padang. Materi yang disampaikan kemudian moderator mempersilahkan para siswa-siswi untuk bertanya(sesi tanya jawab) terkait tentang pengaruh LGBT dan pergaulan bebas.
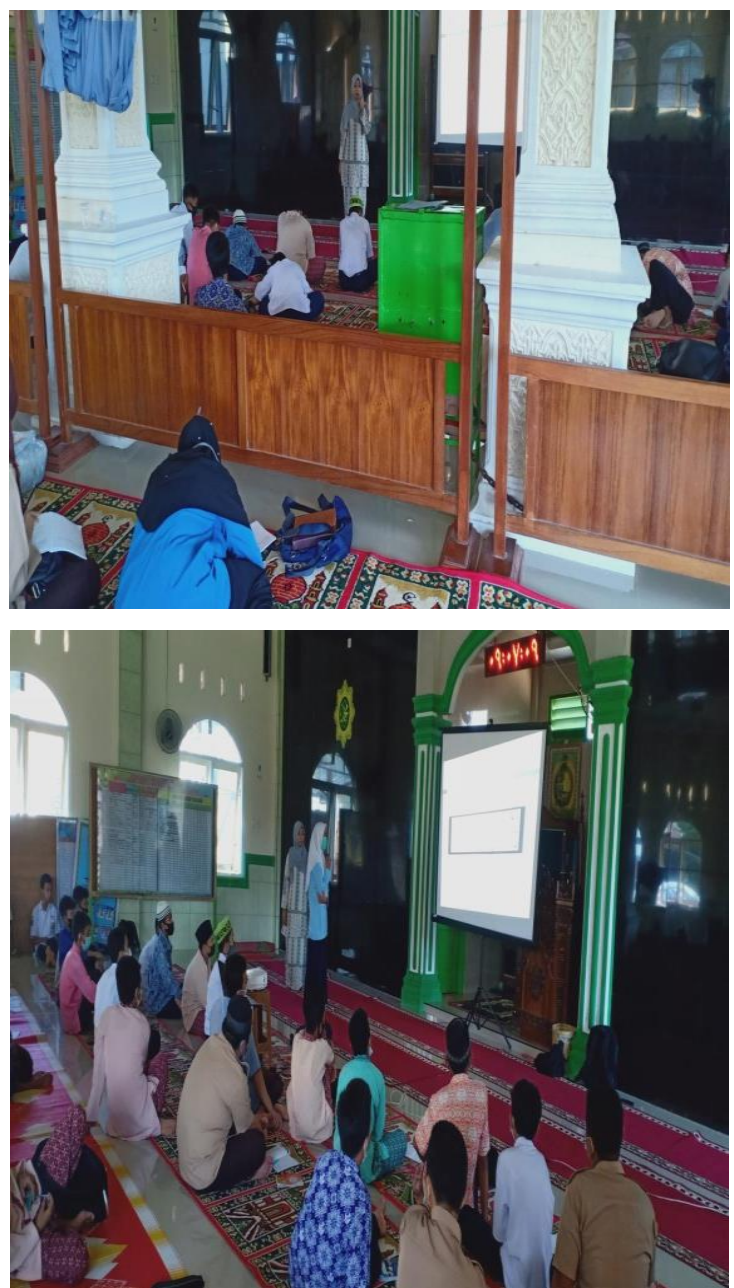


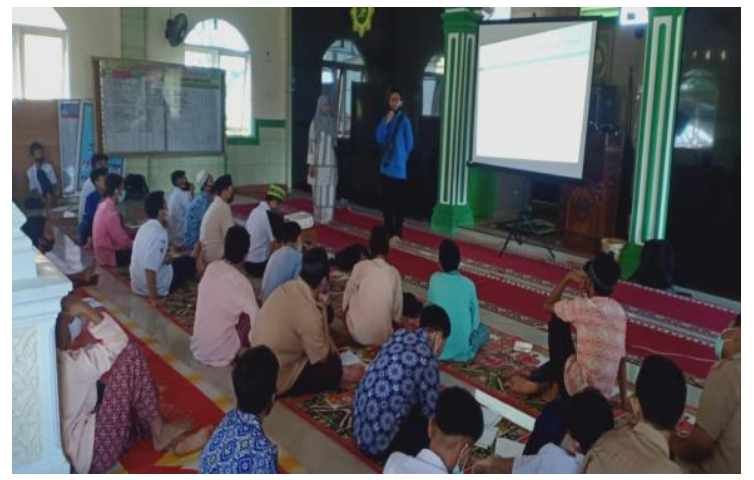

Gambar1. Kegiatan Penyuluhan Pergaulan Bebas dan LBGT

Dampak perilaku pergaulan bebas adalah menurunnya prestasi sekolah, putus sekolah, dan sebagainya. Pergaulan bebas ini sudah merajalela dikalangan pelajar. Dahulu orang yang berduaduaan dianggap sebagai orang yang tidak memiliki rasa malu, apalagi sampai berpelukan dan berciuman, sangat ditentang oleh masyarakat dan langsung terkena hukum adat dengan cara dinikahkan atau membayar uang adat, yaitu dengan cara kawin cerai dimana pihak laki-laki wajib untuk membayar uang adat kepada pihak perempuan sesuai dengan jumlah uang yang diminta oleh pihak perempuan.

Dalam Islam LGBT dikenal dengan dua istilah, yaitu Liwath (gay) dan Sihaaq (lesbian). Liwath (gay) adalah perbuatan yang dilakukan oleh laki-laki dengan cara memasukan dzakar (penis)nya kedalam dubur laki-laki lain. Liwath adalah suatu kata (penamaan) yang dinisbatkan kepada kaumnya Luth karena kaum Nabi Luth 'Alaihis salam adalah kaum yang pertama kali melakukan perbuatan ini (Hukmu al-liwath wa alSihaaq, hal. 1). Allah SWT menamakan perbuatan ini dengan perbuatan yang keji dan melampaui batas (musrifun). Sebagaimana Allah terangkan dalam al Quran yang artinya“'Dan (Kami juga telah mengutus) Luth (kepada kaumnya). (Ingatlah) tatkala dia berkata kepada mereka: "Mengapa kamu mengerjakan perbuatan keburukan itu, yang belum pernah dikerjakan oleh seorang pun (di dunia ini) sebelummu. Sesungguhnya kamu mendatangi lelaki untuk melampiaskan nafsumu (kepada mereka), bukan kepada wanita, bahkan kamu ini adalah kaum yang melampaui batas." (TQS. Al 'Araf : 80 - 81).

Oleh karena itu, sudah dipastikan akar masalah munculnya penyimpangan kaum LGBT saat ini adalah karena ideologi sekularisme yang dianut kebanyakan masyarakat Indonesia. Sekularisme adalah ideologi yang memisahkan agama dari kehidupan masyarakat memandang pria ataupun wanita hanya sebatas hubungan seksual semata. Oleh karena itu, mereka dengan sengaja menciptakan fakta-fakta yang terindera pikiran-pikiran yang mengundang hasrat seksual di hadapan pria dan wanita dalam rangka membangkitkan naluri seksual, semata-mata mencari kepuasan. Mereka menganggap tiadanya pemuasan naluri ini akan mengakibatkan bahaya pada manusia, baik secara fisik, psikis, maupun akalnya. Tindakan tersebut merupakan suatu keharusan karena sudah menjadi bagian dari sistem dan gaya hidup mereka. Tidak puas dengan lawan jenis, akhirnya pikiran liarnya berusaha mencari kepuasan melalui sesama jenis bahkan dengan hewan sekalipun, dan hal ini merupakan kebebasan bagi mereka. 
Allah SWT berfirman :

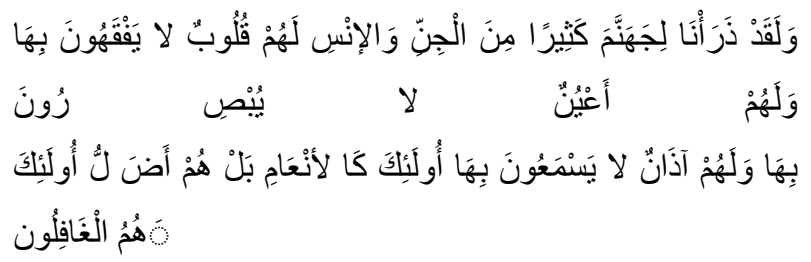

"Dan sesungguhnya Kami jadikan untuk isi neraka Jahannam kebanyakan dari jin dan manusia, mereka mempunyai hati, tetapi tidak dipergunakannya untuk memahami (ayat-ayat Allah) dan mereka mempunyai mata (tetapi) tidak dipergunakannya untuk melihat (tanda- tanda kekuasaan Allah), dan mereka mempunyai telinga (tetapi) tidak dipergunakannya untuk mendengar (ayat-ayat Allah). Mereka itu sebagai binatang ternak, bahkan mereka lebih sesat lagi. Mereka itulah orang-orang yang lalai" (TQS Al 'Araf : 179).

Melalui kegiatan ini, tim pengabdi memberikan ilmu dan informasi mengenai pergaulan bebas dan LGBT, serta bagaimana halhal negatif yang ditimbulkan dari pergaulan bebas dan LGBT dalam kehidupan. Selama kegiatan, peserta antusias untuk mendengarkan serta bertanya kepada penyaji. Kegiatan ini memberikan dampak positif yaitu memperkenalkan kepada remaja mengenai hal-hal mengenai pergaulan bebas dan LGBT sehingga mereka bisa menghindari serta menjauhi perilaku tidak baik ini dalam keseharian.

\section{SIMPULAN}

Perkembangan teknologi yang telah banyak memberi pengaruh buruk bagi remaja sehingga menyebabkan terjadinya kenakalan remaja.
Adanya arus modernisasi pada era ini memberikan kemudahan bagi remaja untuk mengakses segala informasi dan seluk beluk mengenai hal-hal yang berbau dengan pergaulan bebas. Kegiatan ini memberikan dampak positif yaitu memperkenalkan kepada remaja mengenai hal-hal mengenai pergaulan bebas dan LGBT sehingga mereka bisa menghindari serta menjauhi perilaku tidak baik ini dalam keseharian.

\section{DAFTAR PUSTAKA}

Roy. 2011. Pemahaman Tentang Seks Kaitanya dengan Sikap Terhadap Hubungan

Seks Pranikah. Skripsi. Fakultas Psikologi UMS.

Rubiah K. Hamzah. 2001. Teknik dan Strategi Membimbing Remaja: Menghadapi Cabaran.

Kuala Lumpur: PTS Publications and Distributors Sdn. Bhd.

Santrock. 2003. Adolescence: Perkembangan Remaja. Jakarta: Erlangga.

Anwar, H. K. (2019). Analisis Faktor- Fakor Penyebab Terjadinya Pergaulan Bebas Pada Remaja Di kota Banda Aceh. Jurnal Ilmiah Bimbingan Dan Konseling, 4(2), 17.

Nadirah, S. (2017). Peranan Pendidikan dalam Menghindari Pergaulan Bebas Anak Usia Remaja. Jurnal Gender Studies, 9(1), 309.

Nurbiyati, T., \& Widyatama, A. (2014). Sosialisasi Bahaya Minuman Keras Bagi Remaja. Jurnal Inovasi Dan Kewirausahaan, 3(3), 187.

Ramdhun, A. B. (2006). Ranjau-Ranjau Pergaulan Bebas. Sanabil Pustaka. 